\title{
Perbandingan deteksi plasmodium spp. dengan cara pemeriksaan rapid diagnostic test dan pemeriksaan mikroskopik
}

\author{
${ }^{1}$ Nur M. Lasena \\ ${ }^{2}$ Victor D. Pijoh \\ ${ }^{2}$ Janno B. Bernadus
}

\author{
${ }^{1}$ Kandidat Skripsi Fakultas Kedokteran Universitas Sam Ratulangi Manado \\ ${ }^{2}$ Bagian Parasitologi Klinik Fakultas Kedokteran Universitas Sam Ratulangi Manado \\ Email: nurmagfiralasena_12264@yahoo.com
}

\begin{abstract}
Malaria is caused by an obligate intracellular protozoa Plasmodium genus that may affect any people residing in its reproductive area. WHO has recommended quick parasite detection methods based on microscopic examination and Rapid Diagnostic Test (RDT) to all patients suspected of malaria before any antimalaria drug was prescribed. This study aimed to compare plasmodium spp. detection methods by using RDT and microscopic examination as the gold standard. The results of comparing RDT to microscopic examination showed $90.47 \%$ sensitivity, $100 \%$ specifity, $100 \%$ positive predictive value, and $87.5 \%$ negative predictive value. Conclusion: Rapid Diagnostic Test could detect malaria plasmodium almost the same as microscopic examination, and could be practically used as an alternative to confirm the diagnosis of malaria.
\end{abstract}

Keywords: rapid diagnostic test, microscope examination, plasmodium spp

\begin{abstract}
Abstrak: Malaria merupakan penyakit yang disebabkan oleh protozoa obligat intrasel dari genus plasmodium yang dapat menyerang siapa saja terutama penduduk yang tinggal di daerah yang sesuai dengan kebutuhan perkembangan nyamuk. WHO merekomendasikan cara cepat mendeteksi parasit berdasarkan diagnosis dengan uji mikroskopik dan Rapid Diagnostic Test (RDT) pada semua pasien yang dicurigai malaria sebelum pengobatan antimalaria diberikan. Penelitian ini bertujuan untuk membandingkan deteksi plasmodium spp. dengan cara pemeriksaan RDT dan pemeriksaan mikroskopik yang merupakan gold standard. Hasil penelitian memperlihatkan bahwa pemeriksaan dengan metode RDT dibandingkan dengan metode mikroskopik menunjukkan sensitivitas $90,47 \%$, spesifitas $100 \%$, nilai prediksi positif 100\%, dan nilai prediksi negatif 87,5\%. Simpulan: Metode pemeriksaan Rapid Diagnostic Test dapat mendeteksi plasmodium malaria kurang lebih setara dengan pemeriksaan mikroskopik, dan dapat dijadikan pilihan (alternatif) untuk menetapkan diagnosis malaria secara praktis.
\end{abstract}

Kata kunci: rapid diagnostik tes, pemeriksaan mikroskopik, plasmodium spp.

Malaria adalah penyakit yang disebabkan oleh protozoa obligat intrasel dari genus plasmodium yang dapat menyerang siapa saja terutama penduduk yang tinggal di daerah dimana tempat tersebut merupakan tempat yang sesuai dengan kebutuhan nyamuk berkembang.

Malaria biasanya ditularkan oleh gigitan nyamuk anopheles yang terinfeksi. Penyakit ini ditandai oleh keadaan lemah dengan demam tinggi paroksismal, mengigil hebat, berkeringat, anemia, dan splenomegali. ${ }^{1}$

WHO merekomendasikan diagnosis berdasar gejala klinis dengan 2 petunjuk: 1) Bila risiko infeksi malaria rendah, 
kemungkinan transmisi malaria minimal, diagnosis berdasarkan adanya demam selama 3 hari dan tidak ditemukan penyebab infeksi lainnya; 2) Bila penderita risiko malaria tinggi dan transmisi malaria sangat tinggi, diagnosis berdasar adanya demam 1 hari disertai adanya anemia, pada anak sering ditandai dengan pucat di telapak tangan. ${ }^{2}$

Untuk pemeriksaan mikroskopik terdapat dua bentuk sediaan yang digunakan yakni hapusan darah tebal dan hapusan darah tipis. Hapusan darah tipis digunakan untuk identifikasi jenis plasmodium, bila dengan preparat darah tebal sulit ditentukan. Kepadatan parasit dinyatakan sebagai hitung parasit (parasit count), dapat dilakukan berdasar jumlah eritrosit yang mengandung parasit per 1000 sel darah merah. Bila jumlah parasit $>100.000 /$ ul darah menandakan infeksi yang berat. Hitung parasit penting untuk menentukan prognosis penderita malaria, walaupun komplikasinya juga dapat timbul dengan jumlah parasit yang minimal. ${ }^{3,4}$

Rapid diagnostic test (RDT) ialah alat yang mendeteksi antigen malaria pada sampel darah yang sedikit dengan tes imunokromatografi. Tes imunokromatografi berdasarkan pada penangkapan antigen parasit dari darah perifer menggunakan antibodi monoklonal atau poliklonal terhadap antigen parasit. Untuk setiap antigen parasit digunakan 2 set antibodi monoklonal atau poliklonal, satu sebagai antibodi penangkap, dan satu sebagai antibodi deteksi. Antibodi monoklonal bersifat lebih spesifik tapi kurang sensitif bila dibandingkan dengan antibodi poliklonal. ${ }^{5}$

Penelitian ini bertujuan untuk membandingkan deteksi plasmodium spp. dengan cara pemeriksaan rapid diagnostic test dan pemeriksaan mikroskopik dari darah penderita yang dicurigai malalria.

\section{METODE PENELITIAN}

Penelitian ini menggunakan uji diagnostik untuk mendapatkan sensitivitas, spesifisitas, nilai duga positif, dan nilai duga negatif dengan membandingkan cara pemeriksaan Rapid Diagnostic Test (RDT) dan pemeriksaan mikroskopik dalam mendeteksi Plasmodium spp. Desain penelitian ialah potong lintang. Penelitian dilaksanakan pada bulan Oktober 2015 sampai Januari 2016. Sampel darah diambil dari pasien yang dirawat di Rumah Sakit Budi Mulia Bitung.

Pemeriksaan RDT dan mikroskopik dilakukan di Laboratorium RS Budi Mulia Bitung dan Laboratorium Parasiologi Klinik Fakultas Kedokteran Universitas Sam Ratulangi Manado.

\section{HASIL PENELITIAN}

Terdapat 35 sampel darah pasien yang dicurigai malaria yang dirawat di RS Budi Mulia Bitung selama 2 bulan. Hasil yang dieproleh ditabulasi dalam bentuk tabel $2 \times 2$.

Tabel 1. Hasil uji diagnostik pada tabel nilai prediktif

\begin{tabular}{lccc}
\hline \multicolumn{4}{c}{ Pemeriksaaan mikroskopik } \\
\hline & Positif & Negatif & Total \\
\hline $\begin{array}{l}\text { Pemeriksaan } \\
\text { Positif }\end{array}$ & 19 & 0 & 19 \\
$\begin{array}{l}\text { RDT } \\
\text { Negatif }\end{array}$ & 2 & 14 & 16 \\
Total & 21 & 16 & 35 \\
\hline
\end{tabular}

\section{Sensitivitas}

$\frac{T P}{T P+F N} \times 100 \% \frac{19}{19+2} \times 100 \%=90,47 \%$

Spesifitas

$\frac{T N}{T N+F P} \times 100 \% \quad \frac{14}{14+0} \times 100 \%=100 \%$

Nilai duga positif

$\frac{T P}{T P+F P} \times 100 \% \frac{19}{19+0} \times 100=100 \%$

Keterangan: $\mathrm{TP}=$ True positive, $\mathrm{TN}=$ True negative, $\mathrm{FP}=$ False positive, $\mathrm{FN}=$ False negative

\section{BAHASAN}

Dari hasil penelitian dilakukan selama 2 bulan di Rumah Sakit Budi Mulia Bitung pada 35 pasien positif malaria secara klinik 
hanya 21 pasien yang positif dan 14 pasien yang negatif plasmodium pada pemeriksaan mikroskopik. Setelah dilakukan uji diagnostik terhadap sampel penelitian pada mikroskopik (gold standard) dan Rapid Diagnostic Test (RDT) didapatkan hasil sensitivitas $90,47 \%$ dan spesifitas $100 \%$.

Dalam penelitian ini didapatkan 14 sampel yang dinyatakan negatif mikroskopik dan juga pada RDT. Juga terdapat sampel yang dinyatakan positif pada pemeriksaan mikroskopik tetapi negatif pada RDT. Pada nilai prediktif positif dan negatif ditemukan $100 \%$ dan $87,5 \%$ yang berarti dalam hal memastikan jika terdapat hasil positif pada uji diagnostik berarti pasien dinyatakan terkena malaria, begitu juga sebaliknya bila dia tidak terkena malaria.

Penelitian dari Desrinawati ${ }^{6}$ tahun 2003 mengenai perbandingan hasil pemeriksaan metoda immunochromatographic test (ICT) dengan pewarnaan Giemsa pada infeksi malaria falsiparum setelah diuji statistik mendapatkan nilai sensitivitas $76,5 \%$, nilai spesifisitas $68,9 \%$, nilai prediksi positif $73,6 \%$, dan nilai prediksi negatif $72,1 \%$. Penelitian yang dilakukan oleh Lambok $^{7}$ tahun 2011 mengenai perbandingan Rapid Diagnostic Test dan pemeriksaan Mikroskopik pada diagnosis malaria mendapatkan sensitivitas $63,8 \%$, spesifisitas $100 \%$, positive predictive value (PPV) $100 \%$, dan negatif predictive value (NPV) 93,5\%. Penelitian Masanja et al. ${ }^{8}$ di Tanzania tahun 2015, mendapatkan sensitivitas Rapid Diagnostic Test (RDT) mencapai $85,3 \%$ dan spesifitas mencapai $95,8 \%$.

Keterbatasan penelitian ini ialah jumlah sampel yang kecil dan terbatasnya waktu penelitian yang dapat memengaruhi hasil penelitian.

\section{SIMPULAN}

Dari hasil penelitian dan bahasan dapat disimpulkan bahwa metode pemeriksaan Rapid Diagnostic Test (RDT) dapat mendeteksi plasmodium malaria kurang lebih setara dengan pemeriksaan mikroskopik, dan dapat dijadikan pilihan (alternatif) untuk menetapkan diagnosis malaria secara praktis.

\section{DAFTAR PUSTAKA}

1. Kamus Kedokteran Dorland (31st ed). Jakarta: EGC, 2010.

2. Setiawati S, Alwi I, Sudoyo A, Simadibrata M, Setiohadi B, Syam A, et al. Ilmu Penyakit Dalam jilid 1 (6th ed). Jakarta: Interna Publishing, 2014.

3. Ayda R, Purnomo. Atlas Diagnostik Malaria. Jakarta: EGC, 2010.

4. Kusuma WAA, Wiradewi L, Herawati $S$, Yasa IWPS. Denpasar: Bagian Patologi Klinik Fakultas Kedokteran Universitas Udayana, 2014.

5. Parasitologi Kedokteran (4th ed). Jakarta: Fakultas Kedokteran Universitas Indonesia, 2013.

6. Desrinawati. Perbandingan hasil pemeriksaan metoda Immunochromatographic Test (ICT) dengan pewarnaan Giemsa pada infeksi malaria falciparum [Skripsi]. Medan: USU; 2003.

7. Siahaan L. Perbandingan rapid diagnostic test dan pemeriksaan mikroskopik pada diagnosis malaria [Skripsi]. Medan: USU; 2011.

8. Masanja I, McMorrow M, Maganga M, Sumari D, Udhayakumar V, McElroy PD, et al. Quality assurance of malaria rapid diagnostic tests used for routine patient care in rural Tanzania: Microscopy versus realtime polymerase chain reaction. Malaria Journal. 2015;14:85.Doi: 10.1186/s12936-015-0597-3. 